\title{
Universiteit
}

Leiden

The Netherlands

\section{Islamic views on International Law}

Berger, M.S.; Meerts P.

\section{Citation}

Berger, M. S. (2008). Islamic views on International Law. In Culture and International Law (pp. 105-117). Cambridge University Press.

Retrieved from https://hdl.handle.net/1887/13547

Version: $\quad$ Not Applicable (or Unknown)

License: $\quad$ Leiden University Non-exclusive license

Downloaded from: $\quad$ https://hdl.handle.net/1887/13547

Note: To cite this publication please use the final published version (if applicable). 


\title{
Chapter 8 \\ ISLAMIC VIEWS ON INTERNATIONAL LAW
}

\author{
Maurits Berger
}

\section{RÉSUMÉ}

La pertinence du droit international islamique est très limitée dans le monde musulman contemporain. Pour tous les sujets du droit international, les pays musulmans adhèrent aux notions et aux pratiques contemporaines, $\mathrm{y}$ compris celles des traités et reconnaissent l'autorité des corps intergouvernementaux et supranationaux. Ceci s'applique même aux pays avec un caractère islamique distinctif.

Cependant, avec le renforcement du fondamentalisme islamique depuis les années 70 , nous voyons également une tendance croissante à appliquer des arguments légaux islamiques aux sujets internationaux. Deux genres d'arguments ont été distingués dans le présent article. L'argument dit de "compatibilité » veut influencer les positions et les notions internationales pour les faire coïncider avec celles de l'Islam. Les exemples sont notamment l'utilisation des normes juridiques internationales modernes et la dénonciation du terrorisme : toutes deux seraient conformes à l'Islam.

L'argument «d'affirmation de soi » emploie l'Islam avec un certain degré de défit et avec le but implicite de réclamer une identité différente de l'Ouest. Cet argument s'exprime principalement dans deux domaines : Droits de l'Homme et sur les questions de guerre et de paix. Les problématiques de Droits de l'Homme liées à l'Islam peuvent être récapitulées comme suit : (in)égalité basée sur la religion, (in)égalité basée sur le genre, et l'utilisation de certaines pénalités. Ces problématiques ont incité les états et certains intellectuels musulmans à développer plusieurs ensembles séparés de droits de l'homme «islamiques » comme alternative aux traités de Droits de l'Homme signés par leurs gouvernements, bien que ces traités islamiques n'aient jamais été mis en application. De façon intéressante, au cours de la discussion islamique sur les Droits de l'Homme il peut y avoir une rhétorique forte rejetant les Droits de l'Homme 
occidentaux, mais le système global des instruments internationaux n'est jamais remis en question.

En ce qui concerne la guerre et la paix, l'argument d'affirmation de soi a été employé par plusieurs états musulmans, notamment lors des deux guerres du Golfe (Irak) au moment desquelles, des arguments islamiques ont été exigés par certains pour entrer ou au contraire s'abstenir d'entrer en guerre contre un autre état musulman. Cependant, une perspective toute différente a été projetée sur les règles islamiques vis-à-vis de la guerre et de la paix par les acteurs nonétatiques et militants comme le Hamas, le Hizbollah et Al-Qaeda. Non seulement ces acteurs emploient le jargon islamique, mais ils ont développé une doctrine islamique pour répondre à leurs besoins et circonstances spécifiques.

\section{INTRODUCTION}

In 1998 the World Islamic Front declared a jihad against 'Jews and Crusaders' for 'occupying' Saudi Arabia, 'devastating' Iraq and 'serving' Israel's interests. The Front's statement did not raise much interest except from a few intelligence agencies. But Osama bin Laden and Ayman al-Zawahiri, two of the five signatories of the 1998 statement, soon became internationally infamous for actually acting upon their threat, and unleashing a worldwide jihad. These two leaders of Al Qaeda regularly issued statements - fatwas - explaining their actions in carefully selected Islamic terms. In their opinion, they were involved in a war of defence that was justified by the rules of Islam and staging military operations like suicide attacks that they claimed were equally warranted by Islam.

Islamic law does indeed provide for rules of war, as it does for rules of peace. But is this the international law that Bin Laden claims to be referring to? Many Muslim scholars disagree. To them, Bin Laden is engaging in a new and distorted interpretation of Islamic law to justify his violent actions. These scholars have quickly engaged in a counter-offensive emphasizing the peaceful side of Islamic international law.

Nowadays the often cryptic jargon of Islamic international law fills the pages of newspapers, analysts' reports, commentaries and books. We read about jihad and hudna, umma and caliphate. What was once the obscure specialty of a few scholars has become a matter of international interest? After the demise of the vast Islamic empire in the tenth century, Islamic international law seems to have reappeared on the world stage. In this article it will be argued that this impression, however valid and convincing it may 
be, contrasts strongly with the facts of the twenty-first century. Islamic international law may be of great historical interest, and a source of inspiration for Islamic militants, but it has no relevance whatsoever for contemporary international law. To make this argument we will first present a brief overview of international law as developed in Islamic history and Islamic doctrine before we will discuss at length the relation between Islam and international law in the contemporary Muslim world.

\section{ISLAMIC INTERNATIONAL LAW ${ }^{1}$}

Islam has elaborate rules on international law. These generally follow Islam's historical developments of conquest and consolidation, followed by disintegration and foreign encroachment. Parallel to the practice of international legal rules there is also a religious perspective on international law.

The Muslim-Arab conquest of the vast area ranging from Morocco to Afghanistan took place within fifty years, leaving the Muslims slightly bewildered at their unexpected success. It also forced them to deal quickly with several issues related to international law like the rules of war and peace, and how one should deal with conquered peoples. In most cases the MuslimArab armies - often small in size, and sent on specific missions - rode out with what in contemporary military terms is called 'Terms of Engagement': rules on how to deal with the enemy, the conquered cities and their inhabitants, the conquered lands and its inhabitants, and, most importantly, strict rules on how to divide the booty.

From an Islamic perspective, the world was divided into two dominions: one where Islam ruled - the House of Islam - and one where Islam did not rule: the House of War. This division and its naming did not imply the impossibility of concluding treaties or initiating official relations. On the contrary. Wars with the Franks (in Spain, and later in the Middle East), Byzantines and Sassanides were mostly concluded by peace treaties negotiated by diplomatic emissaries. Also, four centuries of intermittent warfare between the

${ }^{1}$ This section draws from the following literature: E. Ashtor, A Social and Economic History of the Near East in the Middle Ages (Berkely and Los Angeles, 1976); M. Al-Ghunaimi, The Muslim Conception of International Law and the Western Approach (The Hague, 1968); M. Khadduri, 'Islam and the Modern Law of Nations,' in 50 AJIL (1956); M. Khadduri, War and Peace in the Law of Islam (Baltimore, 1955); S. Mahmassani, 'The Principles of International Law in the Light of Islamic Doctrine,' 117(I) Recueil des Cours (1966). 
Islamic and Byzantine empires did not prevent them from engaging in continuous trade and entering into diplomatic relations. Later, in the twelfth and thirteenth centuries, many trade treaties were negotiated between Muslim rulers and Italian city-states like Genoa and Venice. War was much less on the East-African and Asian frontiers of the Islamic Empire, and trade as well as diplomatic relations continued uninterrupted for many centuries.

The division of sovereignty into two realms did not necessarily reflect a parallel division of inhabitants, since many non-Muslims resided on Muslim territory. Once the conquests were consolidated, the Muslims ruled over vast regions of which the inhabitants were not Muslim, but Christian, Jewish or Zoroastrian. Forced conversion was hardly practised, meaning that for several centuries the Muslims were a minority in their own empire. The concept of nationality was non-existent in both the practice and doctrine of early Islam, but status was determined on the basis of religion. One contemporary scholar reflected that Islamic international law is merely an extension of Islamic law dealing with relations between Muslims and non-Muslims, whether within or outside the realm of Islam. ${ }^{2}$

Given the division of sovereignty into two dominions, the following categories of persons were developed. Non-Muslims were either residents of the House of War (harbis), or temporary visitors to the House of Islam (musta'mins - 'those with safe conduct'), or residents of the House of Islam (dhimmi). In the latter two cases they were subject to Islamic law, with the exception of specific rules relating to their religion. For instance, they were allowed to trade in alcohol and pork, and to apply their own family laws. Muslims, on the other hand, were considered to always remain under the sovereignty of Islamic law, even if they travelled into non-Muslim countries, however imaginary the enforcement of that law may have been. At the same time, Islamic law also obliged the Muslim abroad to abide by the rules of those countries, unless they contradicted basic principles of Islamic law.

The tenth and eleventh centuries presented the contradictory situation of the consolidation of international law, on the one hand and, on the other, the disintegration of the Islamic empire into emirates, khanates, sultanates and even competing caliphates, with Franks invading from the West and Mongols from the East. Only much later, towards the nineteenth century, did new large empires arise like the Moghuls in India, the Safavids in Iran and the

\footnotetext{
${ }^{2}$ Khadduri, War and Peace in the Law of Islam, p. 120.
} 
Ottomans. But they were quickly threatened by the encroaching power of European colonialism. The Ottoman Empire, for example, entered into treaties with almost every European state, mostly dealing with special regulations for foreign nationals in the Ottoman Empire. Sometimes these treaties even extended to local Christians and Jews. The ensuing immunities and exemptions - known as 'Capitulations' - constituted a new species of international law.

From the nineteenth century onwards, we see the emergence of modern nation states in the Muslim world. Their modernity is reflected, from a legal perspective, in the adoption of Western legal systems and laws, the introduction of the concepts of citizenship and nationality (i.e., the abolition of the distinction between Muslim and non-Muslim) and participation as members of the international community in international relations as conducted and developed on a worldwide scale.

\section{ISLAMiC AND Muslim COUNTRIES}

Before we continue our discussion on international law in the contemporary Muslim world, we must reflect on a few definitions. It is quite common for observers to assert that 'Islamic countries' adhere by default to Islamic laws and hence Islamic international law. While the conclusion drawn is mistaken, its reasoning is logical and therefore understandable. To avoid such a priori misconceptions, a clear distinction will be made in the following between 'Islamic' and 'Muslim' countries.

'Muslim' countries denote countries that have a majority Muslim population. There are approximately fifty such countries. ${ }^{3}$ It must be noted that the majority criterion excludes countries with Muslim minorities that are much larger in number than many Muslim majority countries. 'Muslim' is here used as an objective and neutral term, merely stating the fact of the religious affiliation of the population, regardless of how this affiliation is effectuated.

${ }^{3}$ Numbers differ based on interpretations and calculations. The CIA Handbook claims to adhere to a strict count of the Muslim population of countries, and comes to 49 majority Muslim countries. The Organization of Islamic Conference, on the other hand, has 57 member states but these include countries like Gabon, Guinea-Bissau, Mozambique and Surinam that do not have an absolute Muslim majority population.

${ }^{4}$ Examples are India and China that would rank number 3 and 9 respectively, on the world list of countries with the largest number of Muslim inhabitants. 
Muslim countries therefore include countries with a distinct Islamic profile like Iran or Saudi Arabia, as well as secular states like Turkey and Syria.

We may prefer the term 'Islamic' to 'Muslim' when discussing Muslim countries that are distinctively religious. This label is definitely subjective, for what makes a country Islamic? If it is its laws, most Muslim countries have Islamic family law in addition to their secular legal statutes, so how much more Islamic laws must be introduced before a country can be called 'Islamic'? Countries like Libya and Pakistan, for instance, apply Islamic criminal law but no other Islamic laws, while Saudi Arabia, Sudan and Iran have extended Islamic law to other fields of law. Another issue is the type of government: Saudi Arabia is a kingdom, Sudan a military dictatorship, and Iran a typical form of theocracy that can at best be described as 'Khomeinism'. Only a few Muslim countries actually officially call themselves 'Islamic' and even the ones that do so have added the un-Islamic notion of 'Republic' to their name. ${ }^{5}$ Labelling a state 'Islamic' therefore depends on various factors, and is mostly in the eye of the beholder. So when the term 'Islamic state' is used in the following, this must not be understood as a factual statement but as the author's interpretation.

Of course, it would be much more preferable if we were to remove the adjectives 'Muslim' and 'Islamic' altogether since we are discussing nation states that in no other part of the world are indicated in terms of religion. ${ }^{6}$ But both the central question in this article and the contemporary state of world affairs demand that we look critically at the religious nature of Muslim states as reflected in their view of international law.

\section{INTERNATIONAL LAW IN THE CONTEMPORARY MUSLIM WORLD}

The relevance of Islamic international law to the contemporary Muslim world is, at best, scant. As mentioned above, Muslim countries acknowledge and often adhere to commonly held standards and conduct of international law. Islamic law has little if any relevance in this respect. On the other hand, it

\footnotetext{
${ }^{5}$ Islamic Republic of Iran, Islamic Republic of Pakistan, Islamic Republic of Mauritania. Afghanistan is the only country that after the fall of the Taliban officially called itself an 'Islamic State'.

${ }^{6}$ This is even the case for Israel, a state established exclusively by and for Jews, where the name 'Jewish state' is rather pejorative.
} 
could also be argued that since contemporary international law does not in general contradict the basic principles of Islamic international law, Muslim countries are effectively applying Islamic law. How appealing this argument may seem to those Muslims who favour a stricter following of Islamic rules has never been an issue: Muslim states, even those who claim to be Islamic in all state conduct, hardly appeal to Islam when it comes to international law. An important exception in this respect is human rights. Another exception is the increasing use of Islamic arguments in cases of war. These issues will be discussed in more detail below.

\subsection{International law}

Let us first establish the general fact that few Muslim countries object to the customs and rules of contemporary international law. On the contrary: international law to them is often one of the few defences against the perceived Western hegemony. Indeed, in the case of the Israeli-Palestinian conflict it is the Muslim countries that strongly criticize the lack of enforcement of rules of international law which, in their view, is much more to the advantage of the Palestinian people than the present status quo. In addition, almost all Muslim countries have signed and ratified most of the important international treaties. Exceptions are few: Saudi Arabia and Pakistan, for instance, have not signed or ratified the International Convention on Civil and Political Rights.

This behaviour implies that Muslim countries not only acknowledge international law as laid down in treaties, but actually allow themselves to be subjected to international law. Of course, political motivations have persuaded some Muslim countries not to ratify or to make reservations to their ratification. But this also applies to the United States of America, one of the most hesitant countries when it comes to surrendering part of its sovereignty to international legal scrutiny.

With regard to issues like conversion of religion and gender equality, however, many Muslim countries that ratified international treaties have made exceptions on the basis of Sharia. The common denominator of these particular issues is that they relate to human rights. 


\subsection{Human rights}

Human rights have become one of the main bones of contention between Western and Muslim countries. The human rights debate, however, can be divided into two different areas. One is distinctively connected to Islam, while the other is related to the human rights violations that are innate to the autocratic rule that is prevalent in many Muslim countries. The human rights issues related to Islam can be summarized as: (in)equality based on religion, (in)equality based on gender, and the use of certain penalties.

There is no need to go into the details of why and how these questions play a role. Suffice it to say that the equality of men and women, especially in the case of family law, and the possibility to convert from Islam to another religion, are considered sensitive issues that compel governments of Muslim countries to make reservations in that respect to the treaties they ratify. This may be the government's position, but it may also very well be caused by domestic politics, for many of these governments are under pressure from local Islamic fundamentalists for whom the prohibition of apostasy and the role of women are very important to their cause.

In addition to these specific issues there is a general and ongoing debate about the alleged Western bias of international human rights treaties. This debate is not limited to Muslim countries, although the recent tension between the Western and Muslim world is also reflected in this respect. It has definitely contributed to increasing activity among Muslim scholars and some Muslim states to present treaties of 'Islamic' human rights as an alternative to human rights treaties signed by most Muslim states. It must be said, however, that these Islamic human rights treaties have never been implemented.

There is one interesting characteristic of this 'clash of human rights': those Muslims who reject 'Western' human rights in favour of Islamic human rights never question the overall system of international treaties. They may disagree on the content, but not on the mechanism of international law as such.

\subsection{Islamic law}

How relevant is Islamic law for Muslim countries' actions in the international arena? Few Muslim countries actually apply Islamic law. Almost all their legal systems, including the laws, are based on European models. Only family law has remained Islamic in most Muslim countries. Since the 1970s there has been an increasing call for the reintroduction of Islamic law. The 
most apparent example thereof is the introduction of Islamic penal law, which was already applicable in several Gulf States, but was first reintroduced in Libya (1974), and later in countries like Iran, Sudan, Pakistan, Afghanistan and Nigeria. Among the advocates of Islamic law it is still being debated whether Islamic laws should replace the existing legal corpus or whether this corpus can also be Islamized, i.e., be reformed in accordance with Islamic law.

Interestingly enough, the call for Islamic law focuses exclusively on the laws and hardly ever on the judiciary system. Moreover, even the concept of 'law' itself - i.e., a corpus of rules promulgated by the legislature and to be enforced by the judiciary - which is quite different from the Islamic legal corpus, is never challenged by the Islamist reformers. Similarly, modern notions like republic and nationality are hardly challenged, even though they have no basis in Islamic law.

Regardless of to what extent Islamic law has been introduced in Muslim countries, it always applies to national laws and therefore remains a domestic issue. Insofar as these domestic laws hampered international relations, they were quickly adapted. This is especially the case in the law of international trade. Saudi Arabia, for instance, one of the few Muslim countries that applies a very strict form of Islamic law even to commercial transactions, has made exceptions for transactions related to the oil industry.

\subsection{The use of Islam in international law}

When operating in the international arena, Muslim countries generally adhere to international law, regardless of how Islamic they have profiled themselves. However, in international law there appears to be an increasing use of arguments based on Islam. Generally speaking, we can distinguish between what I suggest should be called the compatible and the self-asserting argument.

The compatible argument is usually in response to Western policies on or interpretations of international law, and basically states that the same conclusions are being reached in accordance with Islam. An example is denouncing terrorism. From all parts of the world Muslim scholars and governments have hastened to declare that Islam is against terrorism. ${ }^{7}$ Another example

\footnotetext{
${ }^{7}$ However, Muslim countries generally put more emphasis on the distinction between terrorists and freedom fighters.
} 
of Islamic compatible argumentation is modern international law itself: this is generally considered perfectly compatible with Islamic international law, or at least with its basic premises.

The self-asserting argument is used to justify certain actions in the international arena with Islam. The term 'self-assertion' is used to indicate a certain degree of defiance and a claim to a distinctly different identity. Human rights is one of them, as discussed above. Another issue is war and peace. Egypt was the first of the independent Muslim nation states ${ }^{8}$ that invoked Islam to wage war, in this case against Israel in 1973. President Sadat had successfully asked the prominent religious scholars of Egypt to issue a religious ruling (fatwa) that allowed him to wage war against Israel. Six years later, he again received a fatwa, this time to enter into a peace agreement with Israel.

This use of Islamic arguments to wage war became very acute during the wars of 1991 and 2003 against Iraq. The central question in both wars was whether waging war against a fellow Muslim nation is allowed in accordance with Islamic law. More pertinent, however, was the question whether collaboration with non-Muslim military forces was allowed. In the specific case of Saudi Arabia, where both questions were answered in the affirmative, fierce debates raged on the presence of non-Muslim troops on Saudi soil - a soil that was deemed more sacred than other Muslim countries due to the presence of the two holiest sites of Islam. ${ }^{9}$

The growing influence of Islamic arguments in determining one's international legal position is not limited to states. Non-state actors, in particular militant Islamic organizations like Hamas, Hizbollah and Al-Qaeda, avail themselves almost exclusively of Islamic arguments to justify their international legal actions. The most notorious example is that of jihad, or the war waged by Muslims to defend their faith and territory. Another example is Hamas' use of hudna to indicate its cessation of hostilities with Israel. The term hudna in this respect has caused much confusion because the common

\footnotetext{
${ }^{8}$ Most contemporary Muslim states were colonized or otherwise occupied by Western powers or were under their sphere of influence and only gained their independence after Second World War. Egypt officially gained its independence in 1922, but the last British troops occupying the Suez Canal zone left in 1956.

${ }^{9}$ Cf. Haddad, Yvonne Yazbeck. 'Operation Desert Storm and the War of Fatwas', in Masud, Messick, Peters and Power (eds.), Islamic Legal Interpretation: Muftis and Their Fatwas (Harvard Middle Eastern Studies, 1996).
} 
translation 'ceasefire' or 'armistice' appeared not to be adequate given the temporary nature that Islamic sources grant to hudna.

The introduction of medieval Islamic legal terminology into contemporary conflict situations means that adaptations are inevitable (although this will be denied by devote Muslims). An example is Hamas' definition of Palestinian territory as an Islamic endowment (waqf) 'consecrated for future Moslem generations until Judgment Day'. ${ }^{10}$ While the waqf is a legal instrument used by private property owners to endow land for future beneficiaries, Hamas has given it a much wider meaning. The political advantage of this definition is that Hamas has lifted Palestine on an equal footing with Israel: both being sacred lands that have been promised by God to a specific people.

Another example of such an adaptation is Hizbollah's restatement of its goal to establish an Islamic state in Lebanon. From a religious point of view the establishment of an Islamic state will always remain the sacred duty of Muslims but, Hizbollah argues, it must be established with the people's consent. Now that Lebanon has a large non-Muslim population that will not consent to such a state, the risk of unrest, chaos and perhaps even civil war if an Islamic state were to be established outweighs the virtue of fulfilling one's religious obligation to actually do so. Hence, Hizbollah has renunciated the active pursuit of establishing an Islamic state without denouncing its religious obligation and desire to do so. ${ }^{11}$

The most belligerent interpreter of the Islamic doctrine on war and peace is Al-Qaeda. It advocates that all means are allowed to drive non-Muslim occupants ('Crusaders and Jews') from Islamic lands, and to fight all those who oppose Islam. The latter also includes those Muslims who are accused of pursuing lives, policies and beliefs that are deemed contradictory to the true teachings of Islam. Hence Al-Qaeda's vehement opposition to most Arab regimes, but also to many Muslim citizens as well. Defining Muslims who are considered to behave in an un-Islamic manner as unbelievers or apostates has greatly expanded Al-Qaeda's enemy that it claims to fight, and has provided justification for killing individual Muslims who 'collaborate' with foreign powers. A parallel doctrine is that the killing of all and any Western citizens from countries which have sent military forces to Islamic countries is allowed, with the argument that these citizens have democratically elected

\footnotetext{
${ }^{10}$ Art. 11 of the 1988 Charter of Hamas.

${ }^{11}$ See, e.g., Joseph Alagha, The Shifts in Hizbullah's Ideology. Religious Ideology, Political Ideology, and Political Program (Amsterdam University Press 2006).
} 
their governments and are therefore individually responsible for the decisions of these governments.

A final and very prominent example of modern Islamic interpretations of the international law of war is that of suicide bombings. Historically speaking, this is a very recent phenomenon - the first suicide bombing taking place in 1983 in Beirut - which has retroactively been grounded in Islamic doctrine. Most Muslim scholars agree that suicide is a sin, but that suicide bombings are allowed when fighting an enemy as long as the targets are military. The attacks on civilians are therefore generally condemned by the Islamic religious establishment, but this does not deter organizations like AlQaeda from practising different interpretations in this respect.

\section{Conclusions}

The relevance of Islamic international law is very limited in the contemporary Muslim world. For all issues of international law, Muslim countries adhere to contemporary notions and practices, including treaties and the authority of intergovernmental and supranational bodies. This even applies to countries with a distinctive Islamic character.

However, with the rise of Islamic fundamentalism since the 1970s we also see a growing tendency to apply Islamic legal arguments to international issues. Two kinds of arguments have been distinguished in this article. The compatible argument wants to make international notions and positions in agreement with those of Islam. Examples are the use of modern international legal standards and the denouncement of terrorism: both are said to be in conformity with Islam.

The self-asserting argument uses Islam with a certain degree of defiance and with the implicit purpose of claiming a different identity than that of the West. This argument expresses itself mainly in two fields: human rights and issues of war and peace. The human rights issues related to Islam can be summarized as (in)equality based on religion, (in)equality based on gender, and the use of certain penalties. These issues have prompted Muslim states and scholars to develop several separate sets of 'Islamic' human rights as an alternative to human rights treaties signed by their governments, although these Islamic treaties have never been implemented. Interesting in the Islamic human rights debate is that there may be a strong rhetoric rejecting 'Western' human rights, but the overall system of international instruments is never questioned. 
With regard to war and peace the self-asserting argument has been used by several Muslim states, particularly in the two Iraq wars where Islamic arguments were used to enter into or refrain from war against a fellow Muslim state. However, Islamic rules of war and peace have been given an entirely new life by militant non-state actors like Hamas, Hizbollah and Al-Qaeda. Not only do they use Islamic jargon, but they have developed Islamic doctrine to meet their specific needs and circumstances.

Can we expect this trend to expand into other fields of international law? Not necessarily. The overriding characteristic of all the mentioned examples is that the use of Islamic arguments serves the self-interest of the one using that argument. Although Muslim states and, in particular, militant non-state actors may act on the basis of true faith, Islam is able to meet very diverse demands. 